\title{
MENANTI PERADILAN KHUSUS PILKADA
}

\author{
Ibnu Affan \\ Dosen Fakultas Hukum Universitas Islam Sumatera Utara Medan \\ aibnu33@yahoo.com
}

\begin{abstract}
According to the 1945 Constitution, Pilkada is not an electoral regime, but it is included in the regime of local government. Therefore, the addition of the Constitutional Court's authority to adjudicate cases of election result disputes is unconstitutional. Decision of the Constitutional Court Number 97/PUU-XI/2003 read out on May 19, 2014 has canceled the Constitutional Court's authority to resolve election disputes. In its decision the Constitutional Court declared that Article 236C of Law no. 12 Year 2008 on Regional Government and Article 29 paragraph (1) letter (e) of Law no. 48 Year 2009 on Judicial Power is declared contradictory to Article 18 and Article 22E of the 1945 Constitution and has no binding legal force. Furthermore to resolve election disputes formed special court as regulated in Law no. 10 of 2016 on the Second Amendment to Law Number 1 Year 2015 Concerning the Stipulation of Government Regulation in Lieu of Law No. 1 of 2014 on the Elections of Governors, Regents, and Mayors Becoming Laws.
\end{abstract}

\begin{abstract}
Abstrak, Menurut UUDNRI Tahun 1945 Pilkada bukan merupakan rezim pemilu, akan tetapi termasuk dalam rezim pemerintah daerah. Oleh karena itu penambahan kewenangan MK untuk mengadili perkara perselisihan hasil pemilu adalah inkonstitusional. Putusan MK Nomor 97/PUU-XI/2003 yang dibacakan pada tanggal 19 Mei 2014 telah membatalkan kewenangan MK untuk menyelesaikan sengketa pemilukada. Dalam putusannya MK menyatakan bahwa Pasal 236C UU No. 12 Tahun 2008 tentang Pemerintah Daerah dan Pasal 29 ayat (1) huruf (e) UU No. 48 Tahun 2009 tentang Kekuasaan Kehakiman dinyatakan bertentangan dengan Pasal 18 dan Pasal 22E UUDNRI Tahun 1945 dan tidak mempunyai kekuatan hukum mengikat. Selanjutnya untuk menyelesaikan perselisihan pilkada dibentuk peradilan khusus sebagaimana diatur dalam UU No. 10 Tahun 2016 tentang Perubahan Kedua Atas Undang-Undang Nomor 1 Tahun 2015 Tentang Penetapan Peraturan Pemerintah Pengganti Undang-Undang Nomor 1 Tahun 2014 Tentang Pemilihan Gubernur, Bupati, Dan Walikota Menjadi Undang-Undang.
\end{abstract}

Kata Kunci: Peradilan Khusus, Pilkada, UUDNRI Tahun 1945

\section{Pendahuluan}

Pemilu dan Pemilukada sebagai perwujudanpelaksanaan kedaulatan rakyat yangdilaksanakan dalam suatu sistem demokrasi langsung tentunya harus sesuai dengan prinsipdan konsep pemilu. Sebagaimana diketahuibahwa Pemilu dilakukan melalui beberapaahapan utama dan kemungkinan terjadi sangketa atau pelanggaran sangat mungkinterjadi di dalam setiap tahapan penyelenggaraan Pemilu. Kemungkinan tersebut bisa disebabkan oleh kecurangan(fraud), kekhilafan (mistake), maupun strategipemenangan pemilu yang tidak 
melanggarhukum tetapi menurunkan kepercayaan publik(non-fraudulent misconduct). ${ }^{1}$

Isu Pemilihan Kepala Daerah atau disingkat dengan Pilkada merupakan sesuatu yang menarik dibahas dewasa ini. Hal ini bukan saja karena isu pilkada serentak yang membuat seksi, tetapi juga proses lahirnya UU Pilkada yang terkesan dramatis juga menjadi menarik untuk dicermati. Masih segar diingatan kita bagaimana hebohnya pengesahan UU No. 22 Tahun 2014 tentang Pemilihan Gubernur, Bupati dan Walikota ketika itu, sehingga memaksa Presiden Susilo Bambang Yudoyono mengeluarkan Peraturan Pemerintah Pengganti UndangUndang (Perppu) No. 1 Tahun 2014 tentang Peraturan Pemerintah Pengganti Undang-Undang Tentang Pemilihan Gubernur, Bupati dan Walikota. Akhirnya Perppu No. 1 Tahun 2014 ini disahkan oleh DPR menjadi UU No. 1 Tahun 2015 tentang Penetapan Peraturan Pemerintah Pengganti Undang-Undang Nomor 1 Tahun 2014 Tentang Pemilihan Gubernur, Bupati dan Walikota Menjadi UndangUndang.

UU No. 1 Tahun 2015 ini, ternyata masih memiliki banyak kekurangan dan kelemahannya sehingga DPR harus kembali merubahnya dengan UU No. 8 Tahun 2015 tentang Perubahan Atas Undang-Undang Nomor 1 Tahun 2015 Tentang Penetapan Peraturan Pemerintah Pengganti Undang-Undang Nomor 1 Tahun 2014 Tentang Pemilihan Gubernur, Bupati, Dan Walikota Menjadi Undang-Undang. Kemudian pada tahun 2016 dirubah kembali dengan UU No. 10 Tahun 2016 tentang Perubahan Kedua Atas Undang-Undang Nomor 1 Tahun 2015 Tentang Penetapan Peraturan Pemerintah Pengganti Undang-Undang Nomor 1 Tahun 2014 Tentang Pemilihan Gubernur, Bupati, Dan Walikota Menjadi Undang-Undang.

Meskipun telah mengalami beberapa kali perubahan, namun ternyata kehadiran UU Pilkada ini belum mampu menjawab semuapermasalahan yang menyangkut tentang pemilihan (pilkada). Setidaknya ada beberapa hal menarik yang patut dibahas dalam tulisan ini terutama yang menyangkut lembaga penyelesaian perselisihan hasil pilkada.

Persoalan penegakan hukum dalam pemilu mencakup tiga ranah hukum yaitu: Sengketa hasil yang diselesaikan di Mahkamah Konstitusi, Penyelesaian perkara pidana pemilu deselesaikan melalui Pengadilan Negeri, Penyelesaian pelanggaran administrasi dilakukan oleh Komisi Pemilihan Umum, Komisi Pemilihan Umum Provinsi, Kabupaten/Kota berdasarkan laporan Bawaslu dan panwaslu. Pembentukan peradilan khusus pemilu sebenarnya suatu solusi untuk

${ }^{1}$ M.B. Zubakhrum Tjenreng, Pilkada Serentak, Penguatan demokrasi di Indonesia, (Jakarta Depok: Pustaka Kemang 2016), hlm 8 
mewujudkan salah satu komponen terpenting dalam azas-azas penyelenggaraan pemilu diantaranya adalah kepastian hukum. ${ }^{2}$

Bertolak dari latar belakang permasalahan sebagaimana telah diuraikan di atas, maka rumusan masalah dalam penelitian ini adalah :

1. Bagaimanakah sistem penyelesaian perselisihan hasil Pemilihan Kepala Daerah menurut UU No. 32 Tahun 2004?

2. Bagaimanakah proses peralihan penyelesaian perselisihan Pemilihan Kepala Daerah dari Mahkamah Agung ke Mahkamah Konstitusi?

3. Bagaimanakah sistem penyelesaian perselisihan hasil Pemilihan Kepala Daerah Pasca Putusan Mahkamah Konstitusi Nomor 97/PUU-XI/2013?

\section{Metode Kajian}

Jenis penelitian yang digunakan dalam penelitian ini adalah penelitian hukum normatif atau disebut juga dengan penelitian hukum kepustakaan yaitu penelitian yang dilakukan dengan cara meneliti bahan pustaka atau data sekunder. $^{3}$

Metode pendekatan yang digunakan yaitu statue approach (pendekatan perundang-undangan) dan analityc approach (pendekatan analitis). ${ }^{4}$ Adapun teknik untuk mengkaji dan mengumpulkan data sekunder yaitu menggunakan studi dokumenter yaitu studi yang mengkaji tentang berbagai dokumen-dokumen, baik yang berkaitan dengan peraturan perundang-undangan maupun dokumendokumen yang sudah ada.

\section{Pembahasan}

\section{Pilkada Merupakan Rezim Pemerintahan Daerah}

Pada Pasal 22E ayat (1) dan ayat (2) UUDNRI Tahun 1945 dikatakan bahwa pemilihan umum dilaksanakan secara langsung, umum, bebas, rahasia, jujur dan adil setiap lima tahun sekali dan diselenggarakan untuk memilih anggota DPR, DPD, Presiden dan Wakil Presiden serta DPRD. Bertolak dari penjabaran Pasal 22E ayat (1) dan (2) dimaksud, dapat dipahami bahwa pilkada bukan merupakan bagian dari rezim pemilihan umum (pemilu) karena rezim pemilu hanya untuk memilih anggota DPR, DPD, Presiden dan Wakil Presiden serta DPRD, tidak termasuk di dalamnya memilih Kepala Daerah (Gubernur, Bupati dan Walikota).

\footnotetext{
${ }^{2}$ Andre Dosdy Ananta Saragih, Tinjauan Yuridis Pentingnya Pembentukan Peradilan Khusus Dalam Pemilu Serentak Menurut Undangundang Pemilihan Kepala Daerah, Jurnal Lex Et Societatis, Vol. V/No. 3/Mei/2017, hlm. 167

${ }^{3}$ Soerjono Soekanto \& Sri Mamuji, Penelitian Hukum Normatif Suatu Tinjauan Singkat, (Jakarta: Raja Grafindo Persada, , 2010), hlm. 13-14.

${ }^{4}$ Ibid., hlm. 19
} 
Aturan mengenai pilkada secara eksplisit diatur dalam bab tersendiri yaitu Bab VI tentang Pemerintahan Daerah. Pasal 18 ayat (4) UUDNRI Tahun 1945 menyatakan secara tegas bahwa : "Gubernur, Bupati, dan Walikota masingmasing sebagai kepala pemerintahan daerah provinsi, kabupaten, dan kota dipilh secara demokratis". Arti demokratis disini dapat dimaknai sebagai pemilihan secara langsung oleh rakyat maupun tidak langsung lewat DPRD. ${ }^{5}$

Oleh karena Pasal 18 ayat (4) UUDNRI Tahun 1945 tentang pemilihan kepada daerah tersebut berada di bawah bab tentang Permintahan Daerah, maka pengaturan pilkada tersebut dalam pelaksanaannya dimuat dalam undang-undang yang termasuk dalam rezim Pemerintahan Daerah. Pilkada sebagai bagian dari rezimpemerintahan daerah, dalam penjabarannya oleh UU No. 22 Tahun 1999 (UU Pemerintahan Daerah sebelumnya) tidak dilaksanakan dalam satu proses pemilihan langsung oleh rakyat, melainkan dilakukan oleh Dewan Perwakilan Rakyat (DPRD). ${ }^{6}$

Sejak berlakunya UU No. 32 Tahun 2004 tentang Pemerintahan Daerah, telah merubah sistem pemilihan Kepala Daerah dari pemilihan melalui DPRD menjadi pemilihan langsung oleh rakyat sebagaimana disebutkan dalam Pasal 56 ayat (1) yang berbunyi : "Kepala daerah dan wakil kepala daerah dipilih dalam satu pasangan calon yang dilaksanakan secara demokratis berdasarkan asas langsung, umum, bebas, rahasia, jujur, dan adil”.

\section{Penyelesaian Perselisihan Hasil Pilkada Melalui Mahkamah Agung}

Konsekuensi Pilkada langsung ini membuahkan tidak sedikit perselishan hasil pemilihan yang harus diselesaikan melalui jalur hukum. Lembaga yang diberi wewenang untuk menangani perselisihan ini adalah Mahkamah Agung (MA) sebagaimana diamanatkan dalam Pasal 106 ayat (1) UU No. 32 Tahun 2004 yang berbunyi : "Keberatan terhadap penetapan hasil pemilihan kepala daerah dan wakil kepala daerah hanya dapat diajukan oleh pasangan calon kepada Mahkamah Agung dalam waktu paling lambat 3 (tiga) hari setelah penetapan hasil pemilihan kepala daerah dan wakil kepala daerah".

Pengaturan penyelesaian keberatan terhadap hasil pilkada dalam UU No. 32 Tahun 2004 bahkan lebih terinci. Undang-undang ini bahkan melakukan pembagian kewenangan penyelesaian perselisihan berdasarkan tingkatan pemilihan. Pada Pasal 106 ayat (3) secara tegas mengatur bahwa pengajuan keberatan kepada MA disampaikan kepada PengadillanTinggi untuk pilkada

\footnotetext{
${ }^{5}$ Maruarar Siahaan, Hukum Acara Mahkamah Konstitusi Republik Indonesia Edisi 2, (Jakarta: Sinar Grafika, 2010), hlm. 166.

${ }^{6}$ Ibid.
} 
provinsi. Sedangkan untuk sengketa dalam pilkada kabupaten/kota disampaikan kepada Pengadilan Negeri. $^{7}$

Untuk melaksanakan kewenangannya dalam memutus perselisihan hasil pilkada tidak seluruhnya harus dilaksanakan oleh MA. Dalam melaksanakan kewenangannya MA dapat mendelegasikan kepada Pengadilan Tinggi untuk memutus perselisihan hasil penghitungan suara pemilihan kepala daerah dan wakil kepala daerah kabupaten/kota sebagaimana diatur dalam Pasal 106 ayat (6) UU No. 32 Tahun 2004, sedangkan perselisihan hasil penghitungan suara pemilihan Gubernur dan Wakil Gubernur dilaksanakan langsung oleh MA. Putusan dalam perselisihan hasil pilkada ini bersifat final dan mengikat. ${ }^{8}$

Ketika perselisihan pilkada ditangani oleh MA ternyata banyak menimbulkan polemik. Suara-suara tidak percaya muncul dari berbagai kalangan yang menganggap MA tidak kredibel dan transparan. Apalagi ketika muncul putusan kontroversi Pengadilan Tinggi Jawa Barat dalam kasus pilkada Kota Depok pada tahun 2005. KPUD Depok telah menetapkan pasangan Nurmahmudi Ismail dan Yuyun Wirasaputra sebagai pemenang dengan perolehan suara sebesar 43,9\%, akan tetapi dianulir oleh Pengadilan Tinggi (PT) Jawa Barat setelah lawannya pasangan Badrul Kamal dan Syihabuddin Achmad mengajukan gugatan terhadap hasil tersebut ke PT Jawa Barat dimana pasangan Badrul Kamal dan Syihabuddin Achmad diputuskan sebagai pemenang oleh PT Jawa Barat. Namun demikian putusan tersebut akhirnya dibatalkan oleh MA setelah pasangan Nurmahmudi Ismail dan Yuyun Wirasaputra mengajukan Peninjauan Kembali (PK). ${ }^{9}$

Apa yang terjadi dalam pilkada Depok tersebut, tentu saja telah melunturkan kepercayaan publik terhadap MA dalam menangani sengketa pilkada. Beban kerja MA yang cukup berat ditambah lagi dengan tunggakan perkara yang terus bertambah menjadi salah satu penyebab munculnya berbagai penyimpangan yang dilakukan oleh aparat peradilan. Sehingga muncul keinginan publik untuk mengalihkan penanganan sengketa pilkada yang selama ini ditangani oleh MA ke lembaga lain. ${ }^{10}$

\section{Peralihan Penyelesaian Perselisihan Hasil Pilkada Dari Mahkamah Agung ke Mahkamah Konstitusi}

\footnotetext{
7 Veri Junaidi, Mahkamah Konstitusi Bukan Mahkamah Kalkulator, (Jakarta: Themis Books, 2013), hlm. 64 . ${ }^{8}$ Ibid.

9 Hukumonline.com, Posisi Dilematis MA dalam Sengketa Pilkada Depok, http://www.hukumonline.com/berita/baca/hol13610/posisi-dilematis-ma-dalam-sengketa-pilkadadepok. diakses pada tanggal 20 Januari 2018.

${ }^{10}$ Veri Junaidi, Mahkamah Konstitusi Bukan Mahkamah Kalkulator, ... hlm. 66
} 
Rendahnya kepercayaan publik terhadap MA telah memunculkan keinginan untuk mengalihkan penanganan sengketa pilkada ke lembaga lain. Lembaga yang dilirik adalah Mahkamah Konstitusi (MK) yang ketika itu sangat dipercaya dan memiliki kredibilitas yang tinggi. Akan tetapi untuk mengalihkan kewenangan ini tidaklah mudah karena kewenangan MK tidak ada mengatur tentang pilkada. Kewenangan MK telah diatur secara limitatif dalam UUDNRI Tahun 1945 dan UU No. 24 Tahun 2003 tentang Mahkamah Konstitusi (MK) dalam Pasal 10 ayat (1) berbunyi :

Mahkamah Konstitusi berwenang mengadili pada tingkat pertama dan terakhir yang putusannya bersifat final untuk :

a) menguji undang-undang terhadap Undang-Undang Dasar Negara Republik Indonesia Tahun 1945;

b) memutus sengketa kewenangan lembaga negara yang kewenangannya diberikan oleh Undang-Undang Dasar Negara Republik Indonesia Tahun 1945;

c) memutus pembubaran partai politik; dan

d) memutus perselisihan tentang hasil pemilihan umum.

Oleh karena dalam UUDNRI Tahun 1945 dan UU No. 24 Tahun 2003, tidak memberi kewenangan kepada MK untuk memutus perselisihan hasil pilkada, maka dilakukan berbagai strategi untuk mengalihkan kewenangan menyelesaikan perselisihan hasil pilkada menjadi kewenangan MK. Strategi pertama dilakukan dengan cara merubah rezim pilkada dari rezim pemerintahan daerah menjadi bagian dari rezim pemilu melalui kehadiran UU No. 22 Tahun 2007 tentang Penyelenggaraan Pemilu. Dalam Pasal 1 angka (4) disebutkan bahwa "Pemilu Kepala Daerah dan Wakil Kepala Daerah adalah pemilihan umum untuk memilih kepala daerah dan wakil kepada daerah secara langsung dalam Negara Kesatuan Republik Indonesia berdasarkan Pancasila dan UUDNRI Tahun 1945.

Konsekuensi yuridis dari ketentuan UU tersebut, menyebabkan terjadinya pergeseran rezim pilkada dari rezim pemerintahan daerah menjadi bagian dari rezim pemilu sehingga terjadi pula perubahan sebutan dari Pilkada menjadi Pemilukada (Pemilihan Umum Kepala Daerah). Dengan perubahan ini, maka rencana untuk mengalihkan penyelesaian sengketa pilkada dari MA kepada MK menjadi semakin terbuka.

Strategi kedua semakin nyata dengan dilakukannya perubahan kedua UU No. 32 Tahun 2004 tentang Pemerintahan Daerah menjadi UU No. 12 Tahun 2008 tentang Perubahan Kedua Atas UU Nomor 32 Tahun 2004 tentang Pemerintahan Daerah yang disahkan pada tanggal 28 April 2008, diadopsi kewenangan MK memutus sengketa pilkada sebagaimana diatur dalam Pasal 236C berbunyi : "Penanganan sengketa hasil penghitungan suara pemilihan kepala daerah dan wakil kepada daerah oleh Mahkamah Agung dialihkan kepada Mahkamah 
Konstitusi paling lama 18 (delapan belas) bulan sejak Undang-Undang ini diundangkan". 11

Ternyata tidak sampai 18 (delapan belas) bulan, pengalihan kewenangan itu ditindaklanjuti melalui penandatanganan Berita Acara oleh Ketua MA dan Ketua MK pada tanggal 29 November 2008. Sejak saat itu secara resmi penyelesaian perselisihan hasil pemilukada menjadi bagian dari wewenang MK.

Tidak sampai disitu saja, kewenangan MK juga semakin diperluas ketika muncul UU No. 48 Tahun 2009 tentang Kekuasaan Kehakiman yang disahkan pada tanggal 24 Agustus 2009. Dalam Pasal 29 ayat (1) huruf (e) ada penambahan kewenangan MK yang berbunyi : "kewenangan lain yang diberikan oleh undangundang”. Penambahan kewenangan ini tentu saja dimaksudkan untuk menguatkan kewenangan MK dalam menangani sengketa pemilukada sebagaimana telah ditetapkan dalam UU No. 12 Tahun 2008. Dengan demikian tidak perlu diragukan lagi bahwa penanganan sengketa pemilukada oleh MK telah memiliki dasar hukum yang kuat.

\section{Pembatalan Kewenangan MK Mengadili Perselisihan Hasil Pemilukada}

Setelah hampir enam tahun MK diberi kewenangan menangani perselisihan hasil pemilukada, akhirnya kewenangan tersebut dibatalkan sendiri oleh MK. Hal ini berawal adanya gugatan uji materi atas kewenangan MK dalam menangani perselisihan hasil pemilukada sebagaimana diatur dalam Pasal 236C UU No. 12 Tahun 2008 dan Pasal 29 ayat (1) huruf e UU No. 48 Tahun 2009 yang diajukan oleh Forum Kajian Hukum dan Konstitusi (FKHK) sebagai Pemohon I, Badan Eksekutif Mahasiswa Fakultas Hukum Universitas Esa Unggul (BEM FH UEU) sebagai Pemohon II, Gerakan Mahasiswa Hukum Jakarta (GMHJ) sebagai Pemohon III, dan Achmad Saifudin Firdaus sebagai Pemohon IV. Para Pemohon mempersoalkan kewenangan MK dalam menangani sengketaPemilukada. Mereka berpendapat bahwa kewenangan MK tersebut bertentangan dengan UUDNRI Tahun $1945 .^{12}$

Perdebatan mengenai kewenangan MK dalam menangani sengketa pemilukada ini mencuat sebagai ekses dari tertangkap tangannya Akil Muchtar yang ketika itu menjabat sebagai ketua MK dalam operasi tangkap tangan (OTT) KPK pada tanggal 2 Oktober 2013. Peristiwa OTT ini sudah barang tentu berakibat pada runtuhnya kepercayaan publik kepada MK yang selama ini diagung-agungkan sebagai sebuah lembaga peradilan yang cukup kredibel dan

\footnotetext{
${ }^{11}$ Ibid.

${ }^{12}$ Agus Sahbani, MK Hapus Kewenangan Sengketa Pemilukada, dalam http://www.hukumonline.com/berita/baca/lt5379f071d5173/mk-hapus-kewenangan-sengketapemilukada.diakses, pada tanggal 22 Januari 2018.
} 
berwibawa. Kekecewaan masyarakat inilah yang menjadi pemicu digugatnya kewenangan MK dalam menangani sengketa pemilukada.

Ternyata gayung bersambut, aspirasi publik ini diterima oleh Hakim Konstitusi dengan mengabulkan gugatan tersebut. Dalam putusannya Nomor 97/PUU-XI/2013 yang dibacakan pada hari Senin, 19 Mei 2014, MK telah membatalkan kewenangannya untuk menyelesaikan sengketa Pemilukada. Dalam putusan itu dinyatakan bahwa Pasal 236C UU No. 12 Tahun 2008 tentang Pemerintah Daerah dan Pasal 29 ayat (1) huruf (e) UU No. 48 Tahun 2009 tentang Kekuasaan Kehakiman dinyatakan bertentangan dengan Pasal 18 dan Pasal 22E UUDNRI Tahun 1945 dan tidak mempunyai kekuatan hukum mengikat.

Sementara dalam pertimbangannya MK menyatakan bahwa dengan menggunakan penafisiran sistematis dan original intent, yang dimaksud pemilihan umum menurut Pasal 22E UUDNRI Tahun 1945 harus dimaknai secara limitatif adalah pemilihan yang dilaksanakan sekali dalam 5 (lima) tahun untuk memilih anggota DPR, DPD, Presiden dan Wakil Presiden serta DPRD. Dengan demikian, jika memasukkan pemilihan kepada daerahmenjadi bagian dari pemilu dan menjadi kewenangan MK, maka tidak sesuai dengan makna original intent dari pemilu itu sendiri.

Hakim konstitusi Patrialias Akbar saat membacakan pertimbangan putusan menyatakan bahwa pemilihan kepala daerah sesuai Pasal 18 UUDNRI Tahun 1945 yang masuk rezim pemerintahan daerah adalah sudah tepat. Meski tidak tertutup kemungkinan pemilihan kepala daerah diatur dalam UU tersendiri, akan tetapi tidak masuk rezim pemilu seperti diatur dalam Pasal 22E UUDNRI Tahun 1945.14 Dengan demikian, berdasarkan putusan MK Pemilihan Kepala Daerah tidak termasuk dalam Rezim Pemilu akan tetapi kembali masuk dalam rezim Pemerintahan Daerah. Konsekuensinya MK tidak lagi berwenang untuk mengadili perselisihan hasil pemilihan kepala daerah.

Menurut Mahkamah penambahan kewenangan MK untuk mengadili perkara perselisihan hasil pemilihan kepala daerah dengan memperluas makna pemilu seperti diatur dalam Pasal 22E UUDNRI Tahun 1845 adalah inkonstitusional. Namun demikian meski MK tidak lagi berwenang mengadili sengketa pemilukada, akan tetapi semua putusan pemilukada tetap dinyatakan sah karena sebelumnya kedua pasal itu merupakan produk hukum yang sah dan valid. Untuk menghindari keragu-raguan, ketidakpastian hukum, dan kevakuman lembaga mana yang berwenang menyelesaikan perselisihan hasil pemilukada karena belum ada undang-undangnya, maka penyelesaian hasil pemilukada tetap menjadi kewenangan MK. ${ }^{13}$

\footnotetext{
${ }^{13} \mathrm{http}: / / w w w . h u k u m o n l i n e . c o m /$ berita/baca/lt58c27a06d91c8/mk-ma-ingatkan-pembentukanperadilan-khusus-sengketa-pilkada, diakses pada tanggal 22 Januari 2018.
} 


\section{Peradilan Khusus Pilkada}

Setelah MK membatalkan kewenangannya mengadili perselisihan hasil pemilukada, mestinya negara berperan aktif menindaklanjutinyadengan membentuk peradilan khusus pilkada. Sebab penanganan perselisihan hasil pilkada di MK hanyalah bersifat transisional sambil menunggu terbentuknya peradilan khusus perselisihan hasil pilkada tersebut. Secara hukum harus dipahami bahwa sesungguhnya penanganan perselisihan hasil pilkada bukanlah merupakan kewenangan MK lagi, akan tetapi seharusnya ditangani oleh badan peradilan khusus. Apalagi payung hukum untuk itu telah ada tertuang dalam UU Pilkada baik dalam UU No. 8 Tahun 2015 tentang Perubahan Atas UndangUndang Nomor 1 Tahun 2015 Tentang Penetapan Peraturan Pemerintah Pengganti Undang-Undang Nomor 1 Tahun 2014 Tentang Pemilihan Gubernur, Bupati, Dan Walikota Menjadi Undang-Undang maupun dalam UU No. 10 Tahun 2016 tentang Perubahan Kedua Atas Undang-Undang Nomor 1 Tahun 2015 Tentang Penetapan Peraturan Pemerintah Pengganti Undang-Undang Nomor 1 Tahun 2014 Tentang Pemilihan Gubernur, Bupati, Dan Walikota Menjadi Undang-Undang.

Pembentukan badan peradilan khusus ini merupakan perintah UU No. 10 Tahun 2016 tentang Perubahan Kedua Atas Undang-Undang Nomor 1 Tahun 2015 Tentang Penetapan Peraturan Pemerintah Pengganti Undang-Undang Nomor 1 Tahun 2014 Tentang Pemilihan Gubernur, Bupati, Dan Walikota Menjadi Undang-Undang. Pada Pasal 157 ayat (1-3) UU No. 10 Tahun 2016 disebutkan bahwa :

1) Perkara perselisihan hasil Pemilihan diperiksa dan diadili oleh badan peradilan khusus;

2) Badan peradilan khusus sebagaimana dimaksud pada ayat (1) dibentuk sebelum pelaksanaan Pemilihan serentak nasional;

3) Perkara perselisihan penetapan perolehan suara tahap akhir hasil Pemilihan diperiksa dan diadili oleh Mahkamah Konstitusi sampai dibentuknya badan peradilan khusus.

Bertolak dari hal itu, sudah seharusnya pembentuk Undang-Undang (pemerintah dan DPR) segera melakukan langkah-langkah konkrit untuk mengimplementasikan perintah UU Pilkada tersebut. Langkah-langkah konkrit dimaksud adalah dengan melakukan percepatan pembentukan peradilan pilkada di daerah-daerah yang potensial. Political will pemerintah diperlukan untuk menghindari potensi permasalahan konstitusionalitas penyelesaian perselisihan hasil pilkada. Tidak ada alasan lagi untuk menunda-nunda pembentukan peradilan khusus pilkada karena memang dibutuhkan seiring dengan perkembangan dan kemajuan perpolitikan dewasa ini. Apalagi perintah MK tersebut telah memasuki 
jangka waktu hampir 4 (empat) tahun. Sementara UU Pilkada yang terakhir disahkan telah hampir 2 (dua) tahun yang lalu.

Pembentukan peradilan khusus pilkada ini tidaklah sulit karena Indonesia telah berpengalaman dalam membuat suatu lembaga peradilan khusus. Ada beberapa peradilan khusus yang telah terbentuk di Indonesia yang diawali dengan pembentukan Pengadilan Hak Asasi Manusia (HAM) tahun 2000, Pengadilan Tindak Pidana Korupsi (Tipikor) tahun 2002, Pengadilan Perikanan tahun 2004, dan Pengadilan Hubungan Industrial (PHI) tahun 2006. Pengadilan-pengadilan khusus di atas dibentuk dan berada dalam lingkungan peradilan umum.

Pembentukan pengadilan khusus ini diatur dalam Pasal 27 UU No. 48 Tahun 2009 tentang Kekuasaan kehakiman yang berbunyi :

1) Pengadilan khusus hanya dapat dibentuk dalam salah satu lingkungan peradilan yang berada di bawah Mahkamah Agung sebagaimana dimaksud dalam Pasal 25;

2) Ketentuan mengenai pembentukan pengadilan khusus sebagaimana dimaksud pada ayat (1) diatur dalam undang-undang.

Ketentuan di atas memberikan kewenangan kepada negara (eksekutif, legislatif dan yudikatif) untuk membentuk peradilan khusus baik di dalam lingkungan peradilan umum, lingkungan peradilan agama, lingkungan peradilan militer maupun lingkungan peradilan tata usaha negara.

Bertolak dari pengalaman-pengalaman Negara Indonesia dalam membentuk beberapa pengadilan khusus sebagaimana tersebut di atas, penulis berkeyakinan tidaklah sulit bagi pemerintah Indonesia (eksekutif dan legislatif) untuk membuat dan mendirikan pengadilan khusus pilkada. Namun yang ditunggu hanyalah kemauan politik (polical will) pemerintah saja. Menurut hemat penulis keberadaan pengadilan pilkada ini dapat saja dibentuk di Pengadilan Tinggi Tata Usaha Negara, mengingat beban kerja Pengadilan Tinggi Tata Usada Negara tidaklah sebanyak dan sepadat seperti di pengadilan umum. Pengadilan ini tidak harus dibentuk di tiap-tiap provinsi, akan tetapi cukup dibentuk di beberapa provinsi saja misalnya untuk wilayah Sumatera dibentuk di Medan, untuk wilayah Jawa dan Madura dibentuk di Jakarta, untuk wilayah Kalimantan dan Bali dibentuk di Pontianak, dan untuk wilayah Indonesia Timur dibentuk di Makasar.

Ciri utama peradilan khusus ini ditandai dengan kehadiran hakim adhoc diantara hakim-hakim karir yang bertugas memeriksa, mengadili dan memutus suatu perkara tertentu. Rekrutmen hakim adhoc dilakukan tersendiri melalui seleksi yang cukup ketat dari berbagai disiplin ilmu. Hakim adhoc direkrut dari orang-orang yang mempunyai keahlian dan pengalaman di bidang tertentu dan memiliki integritas yang tinggi. Dengan demikian diharapkan pengadilan pilkada ini mampu menjawab tantangan masa depan yang semakin kompleks dengan 
menghasilkan putusan-putusan yang berkualitas dan berkeadilan melalui proses peradilan yang sederhana, cepat dan berbiaya ringan.

\section{Penutup}

Bertolak dari paparan tersebut di atas, maka dapat ditarik kesimpulan sebagai berikut :

Pada awalnya penyelesaian perselisihan hasil Pemilihan Kepala Daerah ditangani oleh Mahkamah Agung sebagaimana diatur dalam UU Nomor 32 Tahun 2004 tentang Pemerintahan Daerah karena rezim Pilkada merupakan rezim pemerintahan daerah sebagaimana diatur dalam Pasal 18 UUDNRI Tahun 1945.

Sejak berlakunya UU No. 12 Tahun 2008 tentang Perubahan Kedua Atas UU Nomor 32 Tahun 2004 tentang Pemerintahan Daerah Penyelesaian perselisihan hasil Pilkada beralih dari Mahkamah Agung ke Mahkamah Konstitusi sebagaimana diatur dalam Pasal 236C UU No. 12 Tahun 2008.

Sejak keluarnya Putusan Mahkamah Konstitusi Nomor 97/PUU-XI/2013 pada hakikatnya MK tidak lagi berwenang menangani perselisihan hasil Pilkada dimana ketentuan ini dipertegas dengan terbitnya UU No. 10 Tahun 2016 yang memerintahkan agar dibentuk Peradilan khusus Pilkada untuk mengadili perselisihan hasil Pilkada.

\section{DAFTAR PUSTAKA}

\section{Buku:}

Andre Dosdy Ananta Saragih, Tinjauan Yuridis Pentingnya Pembentukan Peradilan Khusus Dalam Pemilu Serentak Menurut Undangundang Pemilihan Kepala Daerah, Jurnal Lex Et Societatis, Vol. V/No. 3/Mei/2017

Maruarar Siahaan, Hukum Acara Mahkamah Konstitusi Republik Indonesia Edisi 2, Jakarta: Sinar Grafika, 2010

Soerjono Soekanto \& Sri Mamuji, Penelitian Hukum Normatif Suatu Tinjauan Singkat, Jakarta: Raja Grafindo Persada, 2010

Veri Junaidi, Mahkamah Konstitusi Bukan Mahkamah Kalkulator, Jakarta: Themis Books, 2013

Zubakhrum Tjenreng, M.B., Pilkada Serentak, Penguatan demokrasi di Indonesia, Jakarta Depok: Pustaka Kemang 2016

\section{Peraturan Perundang-Undangan:}

Undang-Undang Dasar Negara Republik Indonesia Tahun 1945. 
Undang-Undang Nomor 10 Tahun 2016 tentang Perubahan Kedua Atas Undang-Undang Nomor 1 Tahun 2015 Tentang Penetapan Peraturan Pemerintah Pengganti UndangUndang Nomor 1 Tahun 2014 Tentang Pemilihan Gubernur, Bupati, Dan Walikota Menjadi Undang-Undang. Lembaran Negara RI Tahun 2016 Nomor 130.

Undang-Undang Nomor 8 Tahun 2015 tentang Perubahan Atas Undang-Undang Nomor 1 Tahun 2015 Tentang Penetapan Peraturan Pemerintah Pengganti Undang-Undang Nomor 1 Tahun 2014 Tentang Pemilihan Gubernur, Bupati, Dan Walikota Menjadi Undang-Undang. Lembaran Negara RI Tahun 2015 Nomor 57.

Undang-Undang Nomor 1 Tahun 2015 tentang Penetapan Peraturan Pemerintah Pengganti Undang-Undang Nomor 1 Tahun 2014 Tentang Pemilihan Gubernur, Bupati dan Walikota Menjadi Undang-Undang. Lembaran Negara RI Tahun 2014 Nomor 245.

Undang-Undang Nomor 8 Tahun 2011 tentang Perubahan Atas Undang-Undang Nomor 24 Tahun 2003 Tentang Mahkamah Konstitusi. Lembaran Negara RI Tahun 2011 Nomor 70.

Undang-Undang Nomor 48 Tahun 2009 tentang Kekuasaan Kehakiman. Lembaran Negara RI Tahun 2009 Nomor 157.

\section{Internet:}

Agus Sahbani, MK Hapus Kewenangan Sengketa Pemilukada, dalam http://www.hukumonline.com/berita/baca/lt5379f071d5173/mk-hapuskewenangan-sengketa-pemilukada.diakses, pada tanggal 22 Januari 2018.

http://www.hukumonline.com/berita/baca/lt58c27a06d91c8/mk-ma-ingatkanpembentukan-peradilan-khusus-sengketa-pilkada, diakses pada tanggal 22 Januari 2018 .

Hukumonline.com, Posisi Dilematis MA dalam Sengketa Pilkada Depok, http://www.hukumonline.com/berita/baca/hol13610/posisi-dilematis-ma-dalamsengketa-pilkada-depok. diakses pada tanggal 20 Januari 2018. 